\title{
INFLUENCE OF IRRIGATION AND NITROGEN FERTILIZATION ON THE AMINO ACID COMPOSITION OF SPRING WHEAT
}

\author{
PaAvo Elonen \\ University of Helsinki, Department of Agricultural Chemistry \\ Lissa Aho and Pekka Korvistornen \\ University of Helsinki, Institute of Food Chemistry and Technology
}

Received January 5, 1972

\begin{abstract}
Sprinkler irrigation on clay soils in southern Finland decreased the protein content of spring wheat flour in five field experiments in the years $1967-70$, by $16 \pm 4$ per cent on an average. The amino acid composition, however, was improved, because the proportion of lysine was increased by $6 \pm 4 \%$. Accordingly, the content of lysine in flour was decreased by irrigation only by $10 \pm 5 \%$. An increase of fertilizer nitrogen from 68 to 144 $\mathrm{kg} / \mathrm{ha}$ increased the protein content of wheat flour by $19 \pm 5 \%$, but the proportion of lysine in the amino acid composition decreased by $9 \pm 4 \%$. Therefore, the lysine content in flour was increased by nitrogen fertilization only by $8 \pm 5 \%$. It seemed as if urea and ammonium nitrate limestone would have had about the same effect on the quantity and quality of wheat protein. As a consequence of the reversed influences of irrigation and nitrogen fertilization on the wheat protein it was possible, by means of irrigation and an additional nitrogen fertilization, to produce 65 per cent higher grain yields without any noteworthy changes in the contents of protein or amino acids.
\end{abstract}

By means of irrigation it is possible to produce rather high wheat yields even in as northern a country as Finland (ElONen, NiEminen and KARA 1967). Irrigation decreases the contents of various nutrients in wheat and especially that of proteins, but an increase in fertilization can eliminate this disadvantage and simultaneously stimulate the effect of irrigation on the grain yields (KAILA and ELONEN 1970).

However, in several investigations it has been found that, as a consequence of an intense nitrogen fertilization, the biological quality of wheat protein may be weakened (Bodo 1961, Larsen and Nielsen 1966, Aykroyd and Doughty 1970). There is very little corresponding information about irrigation.

The object of the present work was to study the effects of irrigation and nitrogen fertilization, separately and together, on the amino acid composition of spring wheat. 


\section{Material and methods}

Experimental fields (Table 1). The field trials were carried out in the years 1967-70 in cooperation with the Finnish Research Institute of Agricultural Engineering. Four of them were in successive years on the same farm, in the neighbourhood of Helsinki, the fifth one (No. 3 in Table 1) about $100 \mathrm{~km}$ farther to the west. The soil in the trials was silty clay with an average $\mathrm{pH}$ of 5.6 (in $0.01 \mathrm{M} \mathrm{CaCl}_{2}$ ) and containing about 4 per cent of organic carbon in the top soil. The subsoils were heavy clay.

Table 1. Soil and fertilization of the experimental fields.

\begin{tabular}{|c|c|c|c|c|c|c|c|c|c|c|}
\hline \multicolumn{2}{|c|}{ Trial } & \multicolumn{3}{|c|}{$\begin{array}{l}\text { Particle-size } \\
\text { composition \% }\end{array}$} & \multirow[t]{2}{*}{$\begin{array}{c}\text { Org. C } \\
\%\end{array}$} & \multirow[t]{2}{*}{$\mathrm{pH}$} & \multicolumn{4}{|c|}{ Fertilization, kg/ha } \\
\hline No & (year) & $<2 \mu$ & $2-20 \mu$ & $>20 \mu$ & & & $\mathrm{N}_{1}$ & $\mathrm{~N}_{2}$ & $\mathbf{P}$ & K \\
\hline 1 & (1967) & 52 & 33 & 15 & 3.4 & 5.4 & 60 & 122 & 43 & 56 \\
\hline 2 & (1968) & 50 & 33 & 17 & 4.0 & 6.1 & 75 & 137 & 44 & 62 \\
\hline 3 & (1969) & 49 & 34 & 17 & 3.9 & 4.7 & 97 & 157 & 57 & 81 \\
\hline 4 & (1969) & 50 & 33 & 17 & 4.0 & 6.1 & 16 & 136 & 59 & 100 \\
\hline 5 & (1970) & 45 & 34 & 21 & 3.9 & 5.8 & 92 & 167 & 63 & 106 \\
\hline \multicolumn{2}{|c|}{ Mean } & 49 & 33 & 18 & 3.8 & 5.6 & 68 & 144 & 53 & 81 \\
\hline
\end{tabular}

Fertilization (Table 1). As a basal dressing $\left(\mathrm{N}_{\mathbf{1}}-\mathrm{P}-\mathrm{K}\right)$, either compound fertilizers (Trials 1-3) or ammoniated PK-fertilizer (Trials 4-5) were used. In Trial 5, $75 \mathrm{~kg} / \mathrm{ha}$ of additional nitrogen as urea or ammonium nitrate limestone was applied. This basal dressing was placed in rows at a depth of $8 \mathrm{~cm}$ and it contained, on an average, $68 \mathrm{~kg} \mathrm{~N}, 53 \mathrm{~kg} \mathrm{P}$ and $81 \mathrm{~kg} \mathrm{~K}$ per hectare. Additional nitrogen on the $\mathrm{N}_{2}$-plots, an average of $76 \mathrm{~kg} / \mathrm{ha}$, was applied either as surface dressing for the shoots as calcium nitrate (Trials $1-2$ ) or urea (Trial 3 ), or the additional nitrogen was placed at a depth of $8 \mathrm{~cm}$ in connection with sowing either as urea or ammonium nitrate limestone (Trials 4-5).

I r rig a tio n. Irrigation was performed by slow rotary sprinklers twice in June, at both times with $30 \mathrm{~mm}$ of drainage ditch water.

Table 2. Yields and protein contents of grains of unirrigated $\left(\mathrm{I}_{0}\right)$ and irrigated $\left(\mathrm{I}_{1}\right)$ spring wheat on two levels of nitrogen fertilization. (Means of four replicates).

\begin{tabular}{|c|c|c|c|c|c|c|c|c|c|}
\hline \multirow[t]{2}{*}{ Trial } & \multirow[t]{2}{*}{ Variety } & \multicolumn{4}{|c|}{ Yield, kg/ha (moisture $15 \%$ ) } & \multicolumn{4}{|c|}{ Protein, $\%$ of DM } \\
\hline & & $\mathrm{I}_{0} \mathrm{~N}_{1}$ & $\mathrm{I}_{0} \mathrm{~N}_{2}$ & $\mathrm{I}_{1} \mathrm{~N}_{1}$ & $\mathrm{I}_{1} \mathrm{~N}_{2}$ & $\mathrm{I}_{0} \mathrm{~N}_{1}$ & $\mathrm{I}_{0} \mathrm{~N}_{2}$ & $\mathrm{I}_{1} \mathrm{~N}_{1}$ & $\mathrm{I}_{1} \mathrm{~N}_{2}$ \\
\hline 1 & Svenno & 2100 & 2170 & 3420 & 4200 & 14.5 & 16.1 & 12.3 & 15.0 \\
\hline 2 & Svenno & 2280 & 2380 & 3870 & 4340 & 16.6 & 18.3 & 13.2 & 14.8 \\
\hline 3 & Norröna & 3940 & 4020 & 4620 & 4930 & 11.4 & 13.0 & 9.9 & 11.4 \\
\hline 4 & Ruso & 2260 & 3600 & 2950 & 5270 & 13.1 & 17.7 & 12.1 & 14.8 \\
\hline 5 & Ruso & 3660 & 3900 & 4230 & 4720 & 15.9 & 17.7 & 13.5 & 16.1 \\
\hline Mean & & 2850 & 3210 & 3820 & 4690 & 14.3 & 16.6 & 12.2 & 14.4 \\
\hline
\end{tabular}


Grain yields and protein contents (Table 2). Irrigation increased the grain yields of spring wheat markedly every year, on an average by $1220 \mathrm{~kg} / \mathrm{ha}$, while the protein contents of grains were decreased, by an average of $2.1 \%$-units. This fall in protein content could be fully prevented by the additional nitrogen fertilization.

A n a ly ses. The air-dried winnowed grains were ground in a Quatromat Junior mill to give flour of 60 to 65 per cent extraction. The flour samples of the replicate plots in each trial were combined and thoroughly mixed.

For determination of protein content in the flour samples, the total nitrogen was analyzed according to the KJELDAHL procedure and multiplied by 5.7 . For determination of the amino acid composition of flour, the flour samples were hydrolyzed with $6 \mathrm{~N}$ hydrochloric acid in sealed tubes under nitrogen atmosphere at $100^{\circ} \mathrm{C}$. The hydrolysis was done in series of four samples so that all treatments, $\mathrm{I}_{0} \mathrm{~N}_{1}, \mathrm{I}_{0} \mathrm{~N}_{2}, \mathrm{I}_{1} \mathrm{~N}_{1}$ and $\mathrm{I}_{1} \mathrm{~N}_{2}$ (Tables 1 and 2), were represented in the same series. Amino acid analyses were carried out with automatic Technicon Amino Acid Analyzer using norleucine as both internal and external standard. The results were expressed as percentages of the sum of 17 acids.

Table 3. Influence of irrigation $\left(\mathrm{I}_{1}\right)$ and additional nitrogen fertilization $\left(\mathrm{N}_{2}\right)$ on the amino acid composition (\%) of wheat flour. (Means of five field experiments).

\begin{tabular}{|c|c|c|c|c|c|c|c|c|}
\hline \multirow{4}{*}{$\begin{array}{l}\text { Grain yield, kg/ha } \\
\text { Protein in grains, \% } \\
\text { Protein in flour, \% }\end{array}$} & \multirow{2}{*}{$\begin{array}{l}\mathrm{I}_{\mathbf{0}} \mathrm{N}_{\mathbf{1}} \\
2847\end{array}$} & \multirow{2}{*}{$\begin{array}{l}\mathrm{I}_{0} \mathrm{~N}_{2} \\
3214\end{array}$} & \multirow{2}{*}{$\begin{array}{l}\mathrm{I}_{\mathbf{1}} \mathrm{N}_{\mathbf{1}} \\
3818\end{array}$} & \multirow{2}{*}{$\begin{array}{l}\mathrm{I}_{\mathbf{1}} \mathrm{N}_{\mathbf{2}} \\
4693\end{array}$} & \multicolumn{2}{|c|}{$\left.I_{1}-I_{0}{ }^{a}\right)$} & \multicolumn{2}{|c|}{$\mathrm{N}_{2}-\mathrm{N}_{1} \mathrm{a}^{\mathrm{a}}$} \\
\hline & & & & & $+1225^{* * *}$ & \pm 330 & $+621^{*}$ & \pm 451 \\
\hline & 14.31 & 16.56 & 12.20 & 14.43 & $-2.12 * * *$ & \pm 0.50 & $+2.24 * * *$ & \pm 0.59 \\
\hline & 13.50 & 15.93 & 11.25 & 13.54 & $-2.32 * * *$ & \pm 0.58 & $+2.36 * * *$ & \pm 0.65 \\
\hline Aspartic acid & 3.94 & 4.07 & 4.14 & 4.03 & +0.08 & \pm 0.26 & +0.01 & \pm 0.26 \\
\hline Threonine & 2.94 & 2.70 & 3.04 & 2.94 & +0.17 & \pm 0.27 & -0.17 & \pm 0.24 \\
\hline Serine & 5.21 & 5.00 & 5.11 & 5.15 & +0.02 & \pm 0.33 & -0.08 & \pm 0.33 \\
\hline Glutamic acid & 34.69 & 36.09 & 34.14 & 34.94 & -0.85 & \pm 1.14 & $+1.10^{*}$ & \pm 1.06 \\
\hline Proline & 13.27 & 12.96 & 13.17 & 13.22 & +0.08 & \pm 0.86 & -0.13 & \pm 0.84 \\
\hline Glycine & 3.59 & 3.61 & 3.72 & 3.66 & +0.09 & \pm 0.21 & -0.02 & \pm 0.18 \\
\hline Alanine & 3.04 & 2.96 & 3.09 & 3.08 & +0.08 & \pm 0.21 & -0.04 & \pm 0.16 \\
\hline Valine & 3.93 & 3.91 & 4.07 & 4.03 & +0.13 & \pm 0.27 & -0.03 & \pm 0.25 \\
\hline Cystine & 1.51 & 1.47 & 1.62 & 1.46 & +0.05 & \pm 0.23 & -0.10 & \pm 0.22 \\
\hline Methionine & 0.81 & 1.05 & 1.02 & 0.83 & 0.00 & \pm 0.23 & +0.02 & \pm 0.25 \\
\hline Isoleucine & 3.28 & 3.32 & 3.49 & 3.54 & $+0.22 *$ & \pm 0.18 & +0.04 & \pm 0.20 \\
\hline Leucine & 7.08 & 7.01 & 7.13 & 6.91 & -0.03 & \pm 0.40 & -0.14 & \pm 0.36 \\
\hline Tyrosine & 3.20 & 3.01 & 2.99 & 3.20 & -0.01 & \pm 0.32 & +0.01 & \pm 0.34 \\
\hline Phenylalanine & 5.23 & 5.27 & 4.92 & 5.17 & -0.20 & \pm 0.22 & +0.14 & \pm 0.17 \\
\hline Lysine & 2.16 & 1.98 & 2.31 & 2.09 & $+0.13^{* *}$ & \pm 0.09 & $-0.20 * * *$ & \pm 0.08 \\
\hline Histidine & 2.33 & 2.15 & 2.17 & 2.23 & -0.04 & \pm 0.18 & -0.06 & \pm 0.17 \\
\hline Arginine & 3.79 & 3.44 & 3.87 & 3.52 & +0.08 & \pm 0.15 & $-0.35^{* *}$ & \pm 0.22 \\
\hline Sum b) & 100.00 & 100.00 & 100.00 & 100.00 & 0.00 & & 0.00 & \\
\hline
\end{tabular}

a) Means with the confidence limits at the $95 \%$ level

b) Tryptophan not counted

\section{Results and discussion}

In Table 3, the amino acid compositions of flour protein are reported as mean values of the five experiments. When judging the results, it should be kept in mind that the 
extraction rate of the flour was relatively low, 60-65 per cent. The protein content of wheat was decreased, in consequence of milling, on an average by $0.82 \%$-units which accords well with the previous investigations (HLYNKA 1964). The milling probably changed also the amino acid composition by decreasing especially the proportions of lysine and arginine and increasing the parts of glutamic acid and proline (HLYNKA 1964, Shoup et al. 1966, Aykroyd and Doughty 1970, FAO 1970).

The amino acid compositions seem to be fairly similar to each other. However, the statistical treatment of the analytical results revealed some significant differences. The additional nitrogen fertilization increased the relative amount of glutamic acid at the expense of lysine and arginine. The result accords well with the previous studies (McELroy et al. 1949, Price 1950, Gunthardt and Mcginnis 1957, Bodo 1961, Sosulski et al. 1963, Larsen and Nielsen 1966, Pessi et al. 1971). The effect of irrigation was almost reverse to that of nitrogen fertilization. Irrigation significantly increased the proportions of lysine and isoleucine.

The changes in the amount of lysine are of especially great importance because, in wheat, lysine is the critical essential amino acid which may restrict the effective utilization of other amino acids. Therefore, the biological value of wheat protein as such is determined by the lysine content (Aykroyd and Doughty 1970).

The additional nitrogen fertilization decreased the proportion of lysine in the amino acid composition, by an average of $0.20 \pm 0.08 \%$-units or $8.9 \pm 3.6$ per cent. On the other hand, the protein content of flour was simultaneously increased by $2.36 \pm 0.65 \%$ units or $19.1 \pm 5.3 \%$. Therefore, the additional nitrogen had a positive effect on the lysine content of the flour. This increase was on an average $8.3 \pm 5.1 \%$.

Irrigation increased the relative amount of lysine in proteins by $0.13 \pm 0.09 \%$-units or $6.3 \pm 4.3 \%$, but there was a decrease in the protein content of flour by $2.32 \pm 0.58$ $\%$-units or $15.8 \pm 3.9 \%$. Thus, the combine influence of irrigation was negative: it decreased the lysine content in flour by $10.5 \pm 4.9 \%$.

The influence of the additional nitrogen fertilization and irrigation on the grain yield, the protein content of flour and the biological value of flour protein can in a concise form be presented as follows:

\begin{tabular}{lcccc} 
& \multicolumn{2}{c}{ without irrigation } & \multicolumn{2}{c}{ with irrigation } \\
& $\mathrm{N}_{1}$ & $\mathrm{~N}_{2}$ & $\mathrm{~N}_{1}$ & $\mathrm{~N}_{2}$ \\
grain yield, $\mathrm{kg} / \mathrm{ha}$ & 2850 & 3210 & 3820 & 4690 \\
protein in flour, $\mathrm{g} / 100 \mathrm{~g}$ & 13.50 & 15.93 & 11.25 & 13.54 \\
lysine in flour, $\mathrm{mg} / 100 \mathrm{~g}$ & 292 & 315 & 260 & 283
\end{tabular}

By increasing the amount of fertilizer nitrogen from 68 to $144 \mathrm{~kg} / \mathrm{ha}$ and by irrigating the wheat fields twice in June, it was possible to increase the grain yields by $1840 \mathrm{~kg} / \mathrm{ha}$ (from 2850 to 4690 ) or $65 \%$ without any noteworthy changes in the protein or lysine contents of wheat flour.

Consequently, there are two reasons why it is profitable to intensify fertilization in connection with irrigation. Firstly, fertilization and irrigation in a combined programme stimulate the effect of each other and result in fairly high and constant grain yields (Table 2). Secondly, by means of nitrogen fertilization it is possible to prevent the decrease of protein and lysine contents in wheat caused by irrigation alone. 
An attempt was also made to study whether different kinds of fertilizer nitrogen might have different effects on the amino acid compositions of wheat flour. In two years, in addition to ammoniated PK-fertilizer, $120 \mathrm{~kg} / \mathrm{ha}$ (Trial 4 in Table 1) or $113 \mathrm{~kg} / \mathrm{ha}$ (Trial 5) of nitrogen, either as urea or ammonium nitrate limestone were applied. These nitrogen fertilizers affected the amount and protein content of the yields in about the same way in both years: the average increase in grain yield was 1850 (from 2380 to 4230 ) $\mathrm{kg} / \mathrm{ha}$ and the increase in protein content of grains was 3.0 (from 12.9 to 15.9 ) $\%$-units. The average amino acid compositions are reported in Table 4.

Table 4. Amino acid compositions (\%) in flour of wheat fertilized by urea (A) or ammonium nitrate limestone (B).

\begin{tabular}{lrrrr}
\hline & A & B & A-B \\
\hline Grain yield, kg/ha & 4180 & 4280 & $-100^{* *} \pm 60$ \\
Protein in grains, $\%$ & 16.0 & 15.9 & +0.1 & \pm 0.2 \\
Protein in flour, $\%$ & 14.9 & 14.7 & +0.2 & \pm 0.6 \\
\hline Aspartic acid & 4.4 & 4.1 & +0.3 & \pm 0.6 \\
Threonine & 2.9 & 3.0 & -0.1 & \pm 0.5 \\
Serine & 5.2 & 4.8 & +0.4 & \pm 0.6 \\
Glutamic acid & 35.9 & 35.4 & +0.5 & \pm 2.4 \\
Proline & 12.6 & 12.7 & -0.1 & \pm 1.5 \\
Glycine & 3.7 & 3.8 & -0.1 & \pm 0.3 \\
Alanine & 3.0 & 3.1 & -0.1 & \pm 0.4 \\
Valine & 4.0 & 4.1 & -0.1 & \pm 0.4 \\
Cystine & 1.4 & 1.7 & -0.3 & \pm 0.4 \\
Methionine & 0.8 & 0.8 & 0.0 & \pm 0.4 \\
Isoleucine & 3.6 & 3.5 & +0.1 & \pm 0.4 \\
Leucine & 7.0 & 6.9 & +0.1 & \pm 0.7 \\
Tyrosine & 2.4 & 2.7 & -0.3 & \pm 0.6 \\
Phenylalanine & 5.4 & 5.6 & -0.2 & \pm 0.7 \\
Lysine & 2.1 & 2.2 & -0.1 & \pm 0.2 \\
Histidine & 2.2 & 2.3 & -0.1 & \pm 0.2 \\
Arginine & 3.4 & 3.3 & +0.1 & \pm 0.4 \\
Sum & 100.0 & 100.0 & 0.0 & \\
\hline
\end{tabular}

There are no significant differences between the amino acid compositions of wheat fertilized by urea or ammonium nitrate limestone. Because of the relatively small research material (only 12 amino acid analyses), the confidence intervals of the means are, however, rather wide. For this reason, no far-reaching conclusions can be drawn.

The main result of this study is that irrigation and nitrogen fertilization affect the protein content and the biological value of wheat protein in entirely opposite ways. This statistically significant result is obtained on the basis of field trials, which are carried out in different years using different wheat varieties and different fertilizations. Therefore, in order to obtain a high yield with good protein quality it is advisable for practical wheat husbandry to apply a combined programme of irrigation and nitrogen fertilization. 


\title{
REFERENCES
}

AYkroyd, W. R. \& Doughty, J. 1970. Wheat in human nutrition. FAO Nutritional Studies 23. 163 p. Rome.

BoDo, G. 1961. Ưber die Veränderungen der Weizenkornproteine durch Stickstoff-Düngung. Getreide und Mehl 11: 75-80.

Elonen, P., Nieminen, L. \& Kara, O. 1967. Sprinkler irrigation on clay soils in Southern Finland. II. Effect on the grain yield of spring cereals. J. Sci. Agr. Soc. Finland 39: 78 -89.

FAO 1970. Amino acid content of foods and biological data on proteins. FAO Nutritional Studies 24. 285 p. Rome.

Gunthardt, H. \& Mcoinnis, J. 1957. Effect of nitrogen fertilization on amino acids in whole wheat. J. Nutrition 61: 167-176.

HLynka, J. 1964. Wheat chemistry and technology. 603 p. St. Paul, Minnesota.

KAILA, A. \& Elonen, P. 1970. Influence of irrigation and supply of available nitrogen on growth and nutrient content of spring wheat. J. Sci. Agr. Soc. Finland 42: 205-215.

LARsen, I. \& Nielsen, J. D. 1966. The effect of varying nitrogen supplies on the content of amino acids in wheat grain. Plant and Soil 24: 299-308.

Mcelroy, L. W., Clandinin, D. R., Lobay, W. \& Pethybridge, S. J. 1949. Nine essential amino acids in pure varieties of wheat, barley and oats. J. Nutrition 37: 329-336.

Pessi, Y., Ylänen, M. \& Syvälahti, J. 1971. The effect of fertilization technique on the grain crop of cereals, primarily on the protein content. Acta Agr. Fenn. 123: 206-216.

Price, S. A. 1950. The amino acid composition of whole wheat in relation to its protein content. Cereal Chem. 27: 73-74.

Shoup, F. K., Pomeranz, Y. \& Deyoe, C. W. 1966. Amino acid composition of wheat varieties and flours varying widely in bread-making potentialities. J. Food Sci. 31: $94-101$.

Sosulski, F. W., Paul, E. A.\& Hutcheon, W. L. 1963. The influence of soil moisture, nitrogen fertilization and temperature on quality and amino acid composition of Thatcher wheat. Can. J. Soil Sci. 43: $219-228$.

\section{SELOSTUS \\ SADETUKSEN JA TYPPILANNOITUKSEN VAIKUTUS KEVÄTVEHNÄN AMINOHAPPOKOOSTUMUKSEEN}

\author{
PaAvo Elonen
}

Helsingin yliopiston maanviljelyskemian laitos, Viikki

\author{
Lissa Ано ja Pekka Korvistornen
}

Helsingin yliopiston elintarvikekemian ja -teknologian laitos, Viikki

Sadetuksen ja typpilannoituksen vaikutusta kevätvehnän valkuaisen laatuun pyrittiin selvittämään tutkimalla viiden sadetus- ja typpilannoituskokeen vehnänäytteiden aminohappokoostumuksia. Kenttäkokeet suoritettiin vuosina 1967-70 hiesusavipelloilla Espoossa ja Kiskossa yhteistyössä Maatalouskoneiden tutkimuslaitoksen kanssa.

Kahdesti kesäkuussa suoritettu sadetus alensi vehnäjauhojen valkuaispitoisuutta keskimäärin 2.3 $(14.7-12.4) \pm 0.6 \%$-yksikköä eli $16 \pm 4 \%$. Samalla valkuaisen laatu kuitenkin parani, sillä sadetus lisäsi tärkeimmän aminohapon, lysiinin, osuutta $6 \pm 4 \%$. Jauhojen lysiinipitoisuus aleni sadetuksen vaikutuksesta siten vähemmän kuin valkuaispitoisuus eli $10 \pm 5 \%$. 
Lisäämällä typpilannoitusta keskimäärin $76(68$ - 144) kg/ha vehnäjauhojen valkuaispitoisuus kohosi $2.3(12.4-14.7) \pm 0.6 \%$-yksikköä eli $19 \pm 5 \%$. Typpilannoitus heikensi kuitenkin valkuaisen aminohappokoostumusta vähentämällä lysiinin osuutta $9 \pm 4 \%$. Siten typpilannoitus kohotti jauhojen lysiinipitoisuutta huomattavasti vähemmän kuin valkuaispitoisuutta, eli $8 \pm 5 \%$. Urea ja oulunsalpietari näyttivät vaikuttavan vehnän valkuaisen määrään ja laatuun likimain samalla tavalla.

Sadetus ja typpilannoitus vaikuttivat siten sadon laatuun vastakkaisilla tavoilla mutta sadon määrään samansuuntaisesti, vieläpä toistensa vaikutusta tehostaen. Niinpä sadettamalla ja typpilannoitusta lisäämällä voitiin tuottaa keskimäärin $1840(2850$ - 4690) kg/ha eli $65 \%$ suurempia vehnäsatoja valkuaisen pitoisuuden ja laadun pysyessä likimain ennallaan. 